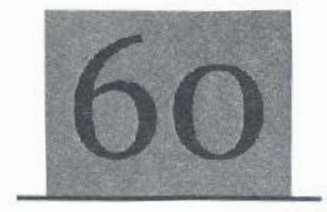

\title{
Plankton communities of Ikpa River, South East Nigeria exposed to sand-dredging activities
}

\author{
Ekwu, A. O./ Udo, N. D.
}

\section{Abstract}

The plankton communties of Ikpa River, downstream from a sand-dredging area were studied for a period of 12 months (Manch 2010 to February 2011), covering dry and wet seasons. Most Physica-chemical parameters ( $\mathrm{pH}$. Turbidity. Silicates, Transparency and Conductivity) exhibited highly significant spatial variation ( $p<0.01$ ), whereas seasonal variation of these variables was not statistically significant $(p>0.05)$. Significant seasonal variation $(p<0.05)$ was however observed in temperature, Dissolved Oxygen, Biochemical Oxygen Demand (BOD). Total Dissolved Solids (TDS), Phosphorus, Nitrates and Conductivity. A total of 51 Taxa of Phytoplankton belonging to 43 genera and 5 families were identified during the period of study. Bacillariophyceae recorded the highest relative abundance with $52.41 \%$, followed by Chtorophyceae with $32.05 \%$, Cycnobacteria with $13.35 \%$, while Euglenophyceae and Dinophyceae contributed $1.26 \%$ and $1.83 \%$, respectively. Among the Diatoms, Melosira granulata was the most dominant species with Shanon - Weiner's Diversity Index ( $H^{i}$ ) of 0.23 and Simpson's Dominance Index (D) of 0.017 . A highly significant variation ( $\left.p<0.011\right)$ was observed in spatial distribution and seasonal abundance of most of the algal groups, whereas taxa occurrence showed no significant difference $(p>0.05)$ among the stations and the seasons. A total of $\&$ taxa of Zooplankton belonging to 4 genera were identified. Rotifera were the most prevalent group with 4 taxa. followed by Cladocera with 2 taxa, while Protozoa and Copepoda recorded I species each. A highly significant spatial and seasonai variation $(p<0.07)$ was observed in Zaoplankton abundance among the stations. The Looplankton dominance profile also showed Rotifers ranking the highest with Shanon - Weiner's Diversity index $\left(H^{\prime}\right)$ of 0.21 and Simpson's Dominance Index (D) of 0.014. Correlation coefficient also showed a highty significunt relationship (r $0.881 ; p<0.01)$ between Zoaplankton and Phytoplankton abundance. Also, a highly significant relationship $(r=0.961 ; p<0.05)$ existed between overall plankton distribution and abundance and water quality parameters. Alternative sources of building materiuls such as Fly Ash and industrial Hemp have been recommended in order to reduce or eliminate the need for sand for building purposes.

\section{Introduction}

ommercial sand dredging is very rampant around Uyo zone of Ikpa River, South East Nigeria. For thousands of years, sand and gravel dredging have been used for construction of roads, buildings, bridges and other infrastructure all over the world. The demand for these resources continues to increase in response to increase in demophoric growth, which is the concept of population growth in a biological sense vis-avis increase in the technology-consumption matrix, posing negative effects on the environment (Wetzel, 2001). Although many familics within the study area rely on the sand dredging as their source of income and sustenance, the dredging has severe impacts on the aquatic environment as well as the adjacent riparian land and vegetation.

The first in line to suffer the impacts are the Plankton. The avalanche of sediment plumes during dredging results in clogging and killing of micro aquatic biota, mostly the plankton. Abiogenic turbidity arising from sand dredging could kill and possibly exterminate some species of Plankton. Where organisms are not killed the turbidity leads to reduced light penetration and consequent reduced phytoplankton primary productivity (Dokuli1, 1994), disturbance and dislodgement/displacement of species attached to the stream bed deposits as well as reduced feeding opportunities.

Plankton are the starting point of energy transfer in the aquatic ecosystem. Their well-being is of paramount importance to the overall health and integrity of the system (Ekwu and Sikoki, 2006). This is because their normal metabolic functioning is central to the processes that take place in the system that influence the fate of contaminants, with respect to biogeochemical cycling, bioavailability, biomagnifications, and bioaccumulation and even direct toxicity to the organisms themselves. This study was carried out to assess the impacts of sand dredging on the plankton communities of Ikpa River. 


\section{Materials and Methods}

Study area. Ikpa River ( $7^{\circ} 53^{\prime} \mathrm{E}$ and $8^{\circ} 07^{\prime} \mathrm{E} ; 5^{\circ} 02^{\prime} \mathrm{N}$ and $\left.5^{\circ} 1^{\prime} 6\right)$, is located South East Nigeria. The river flows through Ntak Inyang, Odiok and empties into Nwaniba, a tributary of the Cross River (Fig.1). Commercial Sand dredging has been going on upstream of the river for over 2 decades. Riparian communities make a living from these activities. However, the consequences of thesc activities on the environment are enormous.

For this study, water samples collected from four stations: above the dredging area, just below area, downstream and from a side pool (backwaters). The sampling was carricd out for 12 months (March 2010 - Feb 2011), covering wet and dry seasons. Vertical samples were collected for both physico-chemical parameters and plankton studies. Water samples were collected once a month from the designated stations using a Hydrobios Nansen type water sampler of 2 litre capacity. Samples for physico-chemical parameters were kept separately in 1.5 litre polyethylene bottles and labeled accordingly.

For quantitative plankton analysis whole samples were collected using the water sampler, while trawl samples were collected for qualitative analysis using standard plankton net, which is a conical (No. 20) net of mesh size 76um net made of silk bolting cloth attached to a slow moving boat. Plankters filtered from each catch were washed ately with Lugol's solution. Samples for biochemical oxygen demand $\left(\mathrm{BOD}_{5}\right.$ ) were collected in $\mathrm{BOD}$ bottles, sealed and later kept in the incubator for 5 days at $20^{\circ} \mathrm{C}$. All samples were $\mathrm{kept}$ in insulated ice boxes at $4^{\circ} \mathrm{C}$ while in the field and during transportation to the laboratory. Identification and Enumeration were done according to guides given by Maosen (1978) and APHA (1985).

Air and water temperature $\left({ }^{\circ} \mathrm{C}\right), \mathrm{pH}$, turbidity (NTU), dissolved oxygen $(\mathrm{Mg} / \mathrm{L})$ and conductivity $\left(\mathrm{mScm}^{-1}\right)$ were measured in situ using a Horiba water checker, model U-10. Secchi disc transparency was measured using a Secchi disc. In the Laboratory, BOD, was determined by obtaining the difference in oxygen levels before and after incubation of water samples (sealed in air-tight containers) at $20^{\circ} \mathrm{C}$ for 5 days (APHA 1985). The oxygen levels (mg/L) werc obtained by in situ readings. Silicate was determined by the Silico-molybdate bluc method of Parsons et al. (1984). Nitrate Nitrogen $\left(\mathrm{NO}_{3}-\mathrm{Nmg} / \mathrm{L}\right)$ was determined by the brucine colorimetric method, ammonium nitrogen $\left(\mathrm{NH}_{4}-\mathrm{Nmg} / \mathrm{L}\right)$ was determincd by the Nesselerization colorimetric method, phosphorus $\left(\mathrm{PO}_{4}{ }^{3-} \mathrm{mg} / \mathrm{L}\right)$ was determined using the randomly Molybdophosphoric acid colorimetric method, while total suspended solids (TSS) was determined by filtration of the sample through a glass fibre filter paper, and the residue on the filter dricd to a constant weight at 103 to $105^{\circ} \mathrm{C}$ (APHA) Data were analyzed using ANOVA, Pearson's Correlation Coeffi. cicnt, Shanon-Weiners Diversity Index (HI) and Simpson's Index of Dominance (D).

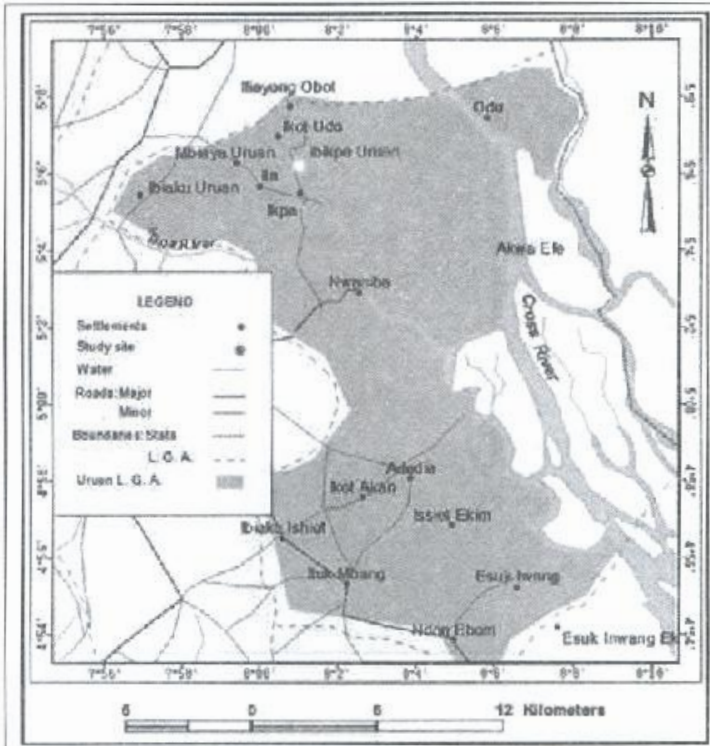

Fig. 1: Location of the study area on the site of Uruan LGA.

\section{Results}

The results of water quality parameters investigated are given in figures 1 a to $1 \mathrm{~d}$. Water temperature ranged from $23.9^{\circ} \mathrm{C}$ to $32.5^{\circ} \mathrm{C}$. Watcr depth ranged from $7.51 \mathrm{~m}$ to $15.2 \mathrm{~m}$ with the highest depth recorded during the wet season. Hydrogen ion concentration ranged from 6.5 w) 9.8 with no significant spatial or seasonal bias $(p>0.05)$. Turbidity showed significant spatial variation ( $p<0.05)$ with the highest value recorded in Station 2 , which was immediately below the dredge area. Also generally highor values of turbidity were observed during the wet scason. A similar trend was observed for total suspended solids (TSS) in which the highest peaks were recorded in Station 2 and generally significantly higher values $(p<0.05)$ during the wet season. Although silicates also showed highest peaks in Station 2, a general trend of higher valuex was rather observed during the dry season. DO, nitrates and phosphates showed no spatial bias but exhibited distinct significant seasonal variation $(\mathrm{p}<0.05)$ with higher values in the wet season. BOD, revealed strong spatial variation $\left(p_{5}<0.05\right)$ with higher values in the bottom samples. 
The results of Phytoplankton and Zooplankton densities are shown in figures 3 and 4, respectively. Five families of phytoplankton were identified in this study as Bacillariophyceae (Diatoms), Chlorophyceae (Green Algac), Cyanobacteria (Blue Green Algae), Euglenophyceace (Euglenoids) and Dinophyceae (Dinoflagellates). The diatoms recorded the highest relative abundance $(53 \%)$, followed by the green algae $(32 \%)$, throughout the sampling period. Only one species of Dinoflagellates was observed throughout the period of investigation. The highest phytoplanklon abundance was recorded in Station 4, while the lowest was observed in Station 2.

Highly significant spatial variation in abundance $(\mathrm{p}<0.01)$ was observed between Station 4 and Station 2 for both phytoplankton and zooplankton. Significant seasonal variation $(\mathrm{P}<0.05)$ was observed in Diatoms and Green algae, with higher taxa numbers recorded in the dry season.

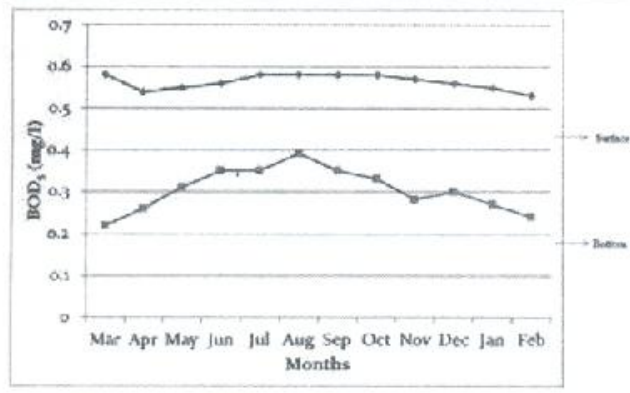

Fig. 2c: Monthly variation of $\mathrm{BOD}_{5}$ in lkpa River.

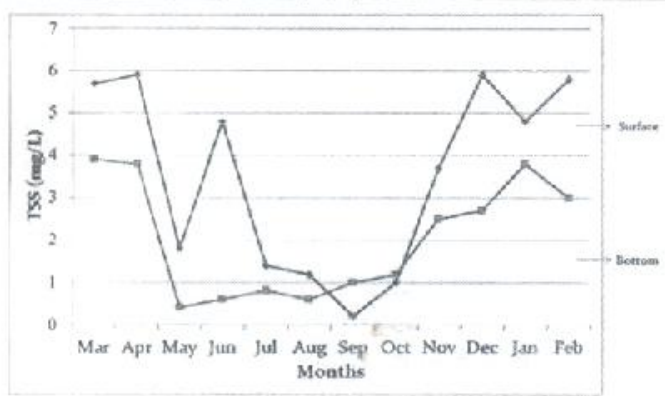

Fig. 2d: Monthly variation of total suspended solids (TSS) in Ikpa River.

Zooplankton comprised an assemblage mostly Rotifers, Cladocera and Copepods. Other groups such as insect larvae and fish larvae were also identified. Rotifers contributed the highest percentage $(37 \%)$ of the zooplankton relative abundance, followed by the Cladocerans with $23 \%$. Similarly, the highest relative abundance of zooplankton was recorded in Station 4 (backwater station), followed by Station 1 and Station 3, while Station 2 contributed the least abundance. .

\section{Discussion}

Overall phytoplankton densities were relatively low compared to other waters within the geographical area (Akpan and Ofem, 1993; Ekwu and Sikoki, 2006). This is probably due to the general perturbation of the area, which prevents build-up of phytoplankton biomass. The low density of phytoplankton in station 2 compared to other stations coincided with the extremely high turbidity and low transparency values at this station. Abiogenic turbidity has been known to light-limit algal productivity (Dokulil, 1994; Lind et al. 1992; Wetzel, 2001). The relatively higher abundance of diatoms in the river system could be attributed to the copious amounts of silicates in the water, occasioned by the sand dredging. Silicates constitute the main nutrient for the buildup of diatom cell structure (Wetzel, 2001). The high level of silica in this water is a deviation from the normal situation of riverine waters which are usually poor in silica (Wetzel, 2001; Hynes, 1971). Generally, the observed increased dry season levels of silicate during this study coincided with increased sand dredging activities by reason of convenience of operation during the period. The observed higher abundance of both phytoplankton and zooplankton in station 4 in comparison with other stations could be due to the rather lentic nature of this station which allows for buildup of plankton densilics. The low densities along the river channel on the other hand, could be due to river discharge, which prevents biomass production and build up of cell densities. Increased river discharge and current speed especially in the wet season has been established as being responsible for low taxa occurrence and cell density in rivers due to low residence time (Lowenherg and Kunzel 1992). Similarly, the observed higher taxa numbers of both phytoplankton and zooplankton during the dry season is attributable to the lower river discharge and higher residence

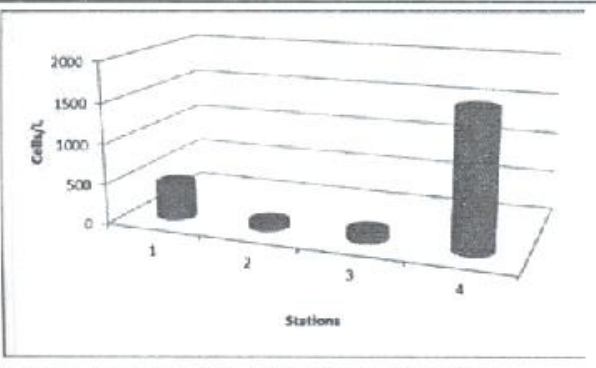

Fig. 3: Spatial distribution of phytoplankton in Ikpa River.

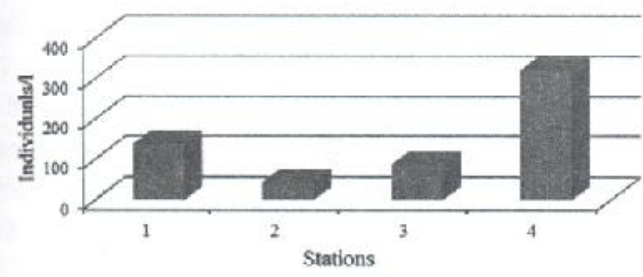

Fig. 4: Spatial distribution of zooplankton in Ikpa River. time of water which favor higher plankton biomass production. The observed dominance of Rotifers among the zooplankton communities could be due to comparative habitat advantage. The bulk of zooplankton identified during this study were contributed from Station 4 , which has a quiescent water column structure. Rotifers have been known to thrive and flourish under quiet and near stagnant conditions (Ovie, 1993; Ekwu and Sikoki, 2005).

As revealed by this study, the demands of anthropogenic perturbations on the Ikpa stream continuum through sand dredging are enormous. Such activities should be regulated by way of regular environmental impact assessments with continuous monitoring.

Furthermore, the use of alternative sources of building materials such as Fly Ash and Industrial Hemp should be encouraged in order to reduce or possibly eliminate the need for sand. Fly Ash has been used extensively in other countries (Jayawardane et al.; Bouzoubaa et al., 2001; Obla, 2008) for building construction of all kinds. Indeed, these workers have demonstrated the advantages of Fly Ash concrete cement over the normal sand concrete. 
Similarly, Industrial Hemp has been used for building (Erwin, 2013; Ceyte, 2008), and this material is fast gaining acceptability and popularity. Indeed, Ceyte, (2008) reported the use of Hempcrete for renovation of the "Maison de la Torque" in Nogent-Sur-Seine in France. It would be worthwhile to adopt and develop the use of these materials to possibly replace the use of sand, in order to safeguard the ecological integrity of the Ikpa River system.

\section{R REFERENCES}

Akpan. E. R. and Ofcm, J. O. (1993). Seasonal variation in water quality of the Cross River. Rev. Hydrobiol. Trop. 26(2): 95-103.

APIIA-AWA. WPCF (1985). Siandard Methods for Examination of Water and Wastewater. 16th Edition. American Public Health Association, Washington, DC. 1268pp.

Bouzoubaa, N., Zhang, M. H. and Malhotra, V. M. (2001). Mechanical properties and durability of concrete made with high-volume fly ash. Cement and Concrete Research. 31(3): 1393-1402.

Ceyte, 1. (2008). Etat Acteurs Prives et Innovation dans le Domaine des Materiaux de Construction Ecologiques: Le Developpement du Beton de Chanvre Depuis. Institut d'Etudes Politiques de Lyon. 278pp.

Dokulil, M. (1994). Environmental Control of Phytoplanklon Productivity in Turbid Systems. Hydrobiologia. 289: 65-72.

Ekwu, A. O. and Sikoki, F. D. (2005). Species composition and distribution of zooplankton in the lower Cross River estuary. Afr. J. Appl. Lool. Envir: Biol. 7:5-10.

Fikwu, A. O. and Sikoki, F. D. (2006). Phytoplankton diversity in the Cross River estuary. J. Appl. Sci. Environ. Mgi. 10(1): 89-95.

Erwin, A. (2013). Industrial hemp. North American Industrial Hemp Council. NAIHC Bulletin. July 18. 30pp.

Hynes, H. B. N. (1971). The Ecology of Running Waters. Liverpool University Press. 555pp.

Jayawardane, D. L. N. B., Ukwatta, U. P. A. S., Weerakoon, W. M. and Pathirana, C. K. (2012). Physical and chemical propertics of fly ash-hased on portland Pozzolana cement. Civil Engineering Research Exchange Symposium. Faculty of Engineering, Universily of Rhuman, India. $11 \mathrm{pp}$.

Lind, O. J., Doyle, R., Vodopich, D. S., Trutter, B. G., Limon, J. G. and Davalos-Lind, L. (1992). Clay turbidity: Regulation of phytoplankton production in a large, nutrient-rich tropical lake. Limnol. Oceanogr. 37:549 565.

Lowenherg, U. and Kunzel, T. (1992). Investigations on the hydrology of the lower Cross River, Nigeria. Animal Reseurch and Development. 35: 72-85.

Maosen, H. (1978). Illustration of Fresthwater Plankton. Agricultural Press, Wuxi City, China. 108pp.

Obla, K. H. (2008). Specifying fly ash for use in concretc. Concrete in Focus Spring 2008. 60-66.

Ovie, S. I. (1993). Composition, seasonal variation and biomass of zooplankton in a small wastewater lagoon. Trop. Freshwat. Biol. 3 : $397-412$

Parsons, T. R., Maita, Y. and Lalli, C. M. (1984). A Manual for Chemical and Biological Methads for Seawater Analysis. Pergamon Press, Oxford. $173 \mathrm{pp}$.

Wetzel, R. G. (2001). Limnology: Lake and River Ecosystems. 3rd Edition. New York: Academic Press, 1006pp. 